\title{
EFFECT OF STORAGE TEMPERATURE AND POSTHARVEST TUBER TREATMENT WITH CHEMICAL AND BIORATIONAL INHIBITORS ON SUPPRESSION OF SPROUTS DURING POTATO STORAGE
}

\author{
Winnie Wanjiku MURIGI ${ }^{1}$, Richard Ombui NYANKANGA ${ }^{1 *}$, Solomon Igosangwa SHIBAIRO ${ }^{2}$ \\ ${ }^{1}$ Department of Plant Science and Crop Protection, University of Nairobi, Kenya \\ ${ }^{2}$ Kibabii University, P.O. Box 1699-50200, Bungoma, Kenya
}

Received: February 2019; Accepted: September 2020

\begin{abstract}
Consumption of ware potatoes in the tropics may be enhanced by storage under conditions that inhibit sprouting, most important of which is the temperature. The effects of storage temperatures $\left(10^{\circ} \mathrm{C}\right.$ and $\left.23{ }^{\circ} \mathrm{C}\right)$ and two alternatives to the chlorpropham (CIPC): 1,4-dimethylnaphthalene (DMN) and peppermint oil (PMO), a biorational inhibitor, were evaluated for tuber sprout suppression at postharvest. Tubers of three cultivars 'Asante', 'Kenya Mpya', and 'Shangi' - with different dormancy lengths were assessed. Storage temperatures and suppressant effects on tuber sprouting, sprout length and sprout numbers per tuber were investigated in replicated storage experiments. Significant differences in sprout inhibition were observed between the two temperatures with suppressive effects higher at $10^{\circ} \mathrm{C}$ than in $23^{\circ} \mathrm{C}$. CIPC had the greatest suppressive effect on tuber sprout inhibition at both temperatures. After 24 weeks of storage, the suppressive effects of CIPC at $10^{\circ} \mathrm{C}$ was $100 \%$ on the three cultivars, whereas all the nontreated tubers sprouted after six ('Shangi'), twelve ('Asante'), fourteen ('Kenya Mpya') weeks of storage. At $23{ }^{\circ} \mathrm{C}$, the effectiveness of CIPC followed the dormancy period of the cultivars, with 'Shangi' recording significantly more sprouted tubers followed by 'Asante' and 'Kenya Mpya'. The inhibition of sprouting by DMN and PMO varied with storage temperatures and cultivars, but were significantly greater than the nontreated tubers. At $10^{\circ} \mathrm{C}$, the effectiveness of DMN treatment was equal to that of CIPC for 'Kenya Mpya' resulting in 100\% inhibition. In the PMO treatments, complete inhibition of sprouting was observed for 18 weeks on cultivars 'Asante', 'Kenya Mpya' and 14 weeks on 'Shangi'. At 23 'C, PMO suppressed sprouts for 14 weeks on 'Asante' and 'Kenya Mpya' and on 'Shangi' for 8 weeks. Storage temperature effects on sprout length and numbers varied with inhibitor type and cultivar. These findings showed that in potato tuber storage, inhibitors can replace low temperature but to an extent depending on the cultivar dormancy character and storage length, thus enabling greater consumption of potatoes in tropical regions.
\end{abstract}

Keywords: potato sprout inhibitors; postharvest; peppermint essential oil; chlorpropham alternatives; 1,4-dimethylnaphthalene

\section{INTRODUCTION}

The production and consumption of potato ( $\mathrm{So}$ lanum tuberosum $\mathrm{L}$.) has increased in Kenya and other tropical countries in recent years, due to the introduction of disease and insect resistant cultivars adapted to tropical highland environments (Lung'aho et al. 2006; Olanya et al. 2012). Postharvest losses of agricultural commodities have been associated with poor or inadequate storage conditions and often accounts for approximately $30 \%$ of losses of total harvested crops (Gustavsson et al. 2011). In the developing countries, the losses of harvested agricultural commodity such as potato (Solanum tuberosum L.) have often been exacerbated due to the elevated storage temperatures at on-farm locations and the suboptimum postharvest processing and produce handling conditions (Wustman \& Struik 2007).

With the increase in market potential of potato tubers in Kenya (Scott et al. 2000), the evaluation of storage temperature conditions that could impact sprout development, tuber weight loss and produce quality have been of considerable importance. Low storage temperatures have often been used to prolong 
the storability of potato by lengthening the natural dormancy (Wiltshire \& Cobb 1996). Published reports have indicated that storage temperatures of $2-4{ }^{\circ} \mathrm{C}$ are suitable for long-term storage of potato, since there is limited sprout development (Paul et al. 2016). However, low temperature storage of ware potatoes destined for either fresh consumption or postharvest processing have shown accumulation of reducing sugars (glucose and fructose) and some degree of sweetening of potato tubers (Sonnewald 2001).

To limit the cold-induced sugar accumulation in potato tubers, long-term storage of potato is done at 8 $12{ }^{\circ} \mathrm{C}$. However, this storage temperature is favorable for sprouting, hence treatment with sprout inhibitors becomes essential for successful long-term storage. For newly developed potato cultivars earmarked for utilization in tropical environments, there are limited published data on storage potential and the effects of storage temperatures and sprout inhibitors on tuber sprout suppression. It has been hypothesized that in the absence of postharvest treatment of potato tubers with sprout suppressants, the rate of sprout development on tubers increases with temperature. In general, at 3$20{ }^{\circ} \mathrm{C}$ temperature range during storage, the length of tuber dormancy is inversely proportional to temperature (Wiltshire \& Cobb 1996). However, the effects of temperature on tuber dormancy depends on cultivar, with different cultivars breaking dormancy at different times even when stored at the same temperature. Respiration rates of potato tubers have been reported to have a minimum at about $4{ }^{\circ} \mathrm{C}$ and increase at higher temperatures (Wustman \& Struik 2007). In the highland tropics where temperature variation occurs rapidly and extensively, the relationship between temperature and tuber dormancy has not been demonstrated.

Chlorpropham (CIPC) - isopropyl N-(3-chlorophenyl)carbamate - mitosis inhibitor, is the most commonly used sprout suppressant on potatoes (Paul et al. 2016; Smith \& Bucher 2012). However, there has been an increasing concern about the toxicity of its residue and degradation of products, which negatively impact the environment and human health (Smith \& Bucher 2012). As a result, in several countries, the use of CIPC and other chemicals are restricted with ban of CIPC in the EU by 2020 (EU 2019/989 of 17 June). There is thus a considerable interest in finding alternative effective potato-sprouting suppressants that have a negligible environmental impact (Paul et al. 2016).
One of the CIPC alternatives is 1,4 dimethylnaphthalene (DMN), a naturally occurring compound in the potato tissues and other plants, and has been shown to be effective in controlling sprout development of stored ware potato tubers and is currently being used in many countries in the world (Campbell et al. 2010; de Weerd et al. 2010; Kleinkopf et al. 2003). DMN mode of action is still not clear, but it has been suggested that it may suspend/suppress normal cell division by inhibiting expression of genes that promote cell division or by enhancing expression of genes that inhibit cell division, which causes extension of dormancy period (Campbell et al. 2010, 2012; Kleinkopf et al. 2003). Other CIPC alternatives that have been found to suppress sprouting and sprout growth include natural compounds containing volatile monoterpenes and essential oils, such as cineole and eucalyptus oil (Vaughn \& Spencer 1991, 1993; Knowles \& Knowles 2008), caraway oil (Gómez-Castillo et al. 2013; Oosterhaven et al. 1995; Şanli et al. 2010; Teper-Bamnolker et al. 2010), peppermint, spearmint, clove, and mint oils (Gómez-Castillo et al. 2013; Kleinkopf et al. 2003; Teper-Bamnolker et al. 2010), menthe oil (Mehta \& Kaul 2002), essential oils from aerial parts of Mentha spicata (Chauhan et al. 2011) and essential oils from Chenopodium ambrosioides and Lippia multiflora (Owolabi et al. 2010). Peppermint oil also has antioxidant and antimicrobial actions (Coleman et al. 2001; Frazier et al. 2004). Peppermint oil acts by physically burning or damaging the meristematic tissue to cease or disrupt cell proliferation (Frazier et al. 2004; Kleinkopf et al. 2003; Vaughn \& Spencer 1991). These plantderived natural compounds leave no residue on the tubers and hence are not toxic. But the efficiency of these alternative inhibitors depends on the cultivar, temperature of storage, progression of tuber dormancy, concentration, time and the number of applications, and the mode of the chemical action. Recently, we have shown that sprout suppression on tubers of tropical-adapted potato cultivars could be achieved for extended storage duration (Nyankanga et al. 2018). However, there are few published reports available in the literature that document the efficacy of these sprout suppressants at different storage temperatures, when applied on tubers of tropical-adapted potato cultivars. Similarly, the suppressive effects of peppermint oil at different storage temperatures, applied to tubers at postharvest as a biorational inhibitor 
relative to chemicals for sprout suppression in a tropic environment have not been adequately quantified. Therefore, the objective of this research was to determine the effects of temperature $\left(10{ }^{\circ} \mathrm{C}\right.$ and $\left.23{ }^{\circ} \mathrm{C}\right)$ on the efficacy of CIPC, DMN and peppermint oil on sprout development on potato tubers of tropicaladapted cultivars following storage for 24 weeks.

\section{MATERIALS AND METHODS}

\section{Potato cultivars and field plot establishment}

Potato tubers of the three commercially cultivated cultivars, 'Shangi' (short dormancy), 'Asante' (medium dormancy) and 'Kenya Mpya' (medium to long dormancy) from Kenya Agricultural and Livestock Research Institute (KALRO, Tigoni) were used in the study (Nyankanga et al 2018). Potato crops were grown from April to July 2013 (cropping season 1) and from October 2013 to January 2014 (cropping season 2) at Kabete Field Station, University of Nairobi, Kenya. The site lies at an altitude of 1,737 meters above sea level and on $1^{\circ} 15^{\prime} \mathrm{S}$ latitude and $36^{\circ} 44^{\prime} \mathrm{E}$ longitude. The cropping location has a bimodal rainfall pattern with maximum rainfall amounts in April and November. The annual rainfall total is about $1,000 \mathrm{~mm}$. The site has maximum and minimum mean temperatures of $24.3^{\circ} \mathrm{C}$ and $13.7^{\circ} \mathrm{C}$, respectively. At the experimental site, the predominant soils are Nitisols, characterized with excessive drainage, dark reddish, friable clay type of soils (Jaetzold et al. 2006).

Potato tubers were planted in $4 \mathrm{~m}$ long by 4 rows plots with a spacing of $0.3 \times 0.75 \mathrm{~m}$ in a completely randomized design with three replications per cultivar. Each plot had four rows and a total of sixty hills. Di-ammonium phosphate (DAP) fertilizer was applied at the planting time at the rate of $150 \mathrm{~kg} \mathrm{P} \cdot \mathrm{ha}^{-1}$ and urea was applied as side dressing after full emergence at a rate of $100 \mathrm{~kg} \mathrm{~N} \cdot \mathrm{ha}^{-1}$. The agronomic practices utilized in the experimental plots were that recommended for potatoes cultivation in the tropical highlands. These consisted of weed management practices, plot ridging and pest control. Freshly harvested potato tubers free of any physical defects and with no evidence of disease occurrence and without any signs of sprouting were selected and maintained for 14 days at room temperature $\left(25^{\circ} \mathrm{C}\right)$ before applying the treatments.

\section{Chemical and biorational inhibitor application and experiment set up}

The experiment consisted of tubers from 3 potato cultivars $\times 4$ treatments (CIPC, DMN, PPO and nontreated - distilled water) $\times 3$ replications with a total of 36 treatment combinations. The experiment was a completely randomized design with three replications per treatment and twenty tubers per replication done in $23{ }^{\circ} \mathrm{C}$ and $10^{\circ} \mathrm{C}$ storage temperatures. The same randomization was utilized for both storage temperatures. For the application of chlorpropham (CIPC), granules containing 95\% a.i. (Sigma-Aldrich, USA) were dissolved in sterile distilled water and subsequently sprayed uniformly on the potato tubers that were thinly spread on a plastic tray, with a dosage of $22 \mathrm{mg} \cdot \mathrm{kg}^{-1}$ of active ingredient. After the treatment, the tubers were wrapped in airtight plastic bags for 24 hours. Twenty tubers per treatment and replication were packed in Khaki bags. The DMN chemical was applied at the rate of $100 \mathrm{mg}$ a.i. $\mathrm{kg}^{-1}$ of potato tuber as liquid aerosol. In the case of PPO, twenty potato tubers were placed in khaki bags and packed in plastic bags to prevent vaporization of the peppermint essential oil. Application of the essential oil treatments was based on the wick method used by Frazier et al. (2004). A filter paper impregnated with PPO was placed between the khaki and polyethylene bag so that no direct contact of the essential oil with potato tubers occurred, but vaporization of PPO exposed the tubers to essential oil. A dosage of $50 \mathrm{ppm}$ per $\mathrm{kg}$ of potato was applied to the tubers for each treatment every 2 weeks. The storage bags were ventilated for 5 minutes twice per week to allow gaseous exchange on the tubers. In the control, distilled water was sprayed onto tubers. After the treatment, tubers were stored at $10{ }^{\circ} \mathrm{C}$ and $23^{\circ} \mathrm{C}$ for 24 weeks. The experiment was conducted two times.

\section{Data collection}

Tubers were visually examined and sprouting was recorded weekly for 24 weeks, to determine the percentage of tubers with sprouts as well as the duration of sprouting inhibition relative to the tubers from the nontreated control, and the number of sprouts $>3 \mathrm{~mm}$ per tuber as well as sprouts length were evaluated. 


\section{Statistical analysis}

Prior to analysis, the data were subjected to tests for normality of variances. In cases where the assumptions of normality and equality variances were not met, the percentage of sprouted tubers was arc square root transformed while the sprout length and number of sprouts per tuber were square root transformed to stabilize the variance prior to analysis. Data were analyzed separately for each experiment by PROC GLM of the Statistical Analysis System, SAS ver. 9.3 (SAS Institute, USA). The effects of chemical and biorational inhibitors, cultivars, as well as storage temperatures on sprout development on tubers $(\%)$ were subjected to analysis of variance.

\section{RESULTS}

\section{Storage temperature, cultivar, and suppressant effects on sprouting of tubers}

The percentage of tubers that developed sprouts varied between storage temperatures $\left(10^{\circ} \mathrm{C}\right.$ vs. $\left.23^{\circ} \mathrm{C}\right)$, duration of storage and cultivars (Table $1 \& 2$ ). In the two seasons, sprouting was significantly influenced by the interaction effect of the temperature, sprout suppressant, cultivar and storage duration (Table $1 \& 2$ ). At $10{ }^{\circ} \mathrm{C}$, no sprouts were observed in the untreated tubers until 10 weeks on 'Asante', 12 weeks on 'Kenya Mpya' and 6 weeks on 'Shangi' cultivars, respectively. In comparison, the percentage of untreated tubers that developed sprouts at $23{ }^{\circ} \mathrm{C}$ occurred at 8 weeks of storage on 'Asante' and 'Kenya Mpya' tubers, and at 2 weeks on 'Shangi' tubers (Table $1 \& 2$ ). For potato treated with CIPC and stored at $10{ }^{\circ} \mathrm{C}$, no sprouts were recorded on tubers of any of the cultivars after 24 weeks of storage. Potato tubers treated with CIPC and stored at $23{ }^{\circ} \mathrm{C}$ developed sprouts at 20 weeks of storage on all the three cultivars (Table $1 \& 2$ ). Tubers treated with DMN and stored at $10{ }^{\circ} \mathrm{C}$ sprouted at 16 and 18 weeks of storage for 'Shangi' and 'Asante', respectively. For 'Kenya Mpya', tubers treated with DMN showed complete suppression of sprout development as no sprouts were observed even after 24 weeks. Tubers treated with DMN and stored at $23{ }^{\circ} \mathrm{C}$ sprouted faster than at $10{ }^{\circ} \mathrm{C}$ with the occurrence of sprouts on tubers at 4 weeks of storage on 'Shangi' tubers, 10 weeks on 'Asante' tubers and 16 weeks of storage on 'Kenya
Mpya' tubers (Table $1 \& 2$ ). Tubers treated with PMO and stored at $10{ }^{\circ} \mathrm{C}$ had no sprouts up to 18 weeks of storage on 'Asante' and 'Kenya Mpya' tubers, but on 'Shangi' tubers, no sprouting occurred up to 14 weeks of storage. At $23{ }^{\circ} \mathrm{C}$, on tubers treated with PMO, sprouts were recorded at 10 weeks of storage on 'Shangi' tubers and at 16 weeks of storage on 'Asante' and 'Kenya Mpya' tubers. Overall, sprout development increased with increased storage period (weeks) for tubers of the three cultivars especially at $23{ }^{\circ} \mathrm{C}$.

After 18 weeks of storage, $100 \%$ of the untreated tubers from the three cultivars developed sprouts regardless of storage temperature in the two seasons (Table $1 \& 2$ ).

\section{Storage temperature, cultivar, and suppressant} effects on sprout length

Sprouts of all cultivars at both storage temperatures and duration were the longest in control tubers (Fig. 1). The effect of inhibitors on sprout length $(\mathrm{mm})$ varied with storage temperatures and duration of storage in the two seasons. In both seasons, tuber sprout lengths were consistently lower at $10{ }^{\circ} \mathrm{C}$ than at $23{ }^{\circ} \mathrm{C}$. The sprouts were longest on the untreated tubers stored at $23{ }^{\circ} \mathrm{C}$ followed by those untreated and stored at $10^{\circ} \mathrm{C}$. The shortest sprouts were on the samples with CIPC treatment. The tubers treated with CIPC and stored at $10^{\circ} \mathrm{C}$ did not have sprouts, even after 24 weeks of storage. Tubers treated with peppermint essential oil had shorter sprouts at $10^{\circ} \mathrm{C}$ than at $23{ }^{\circ} \mathrm{C}$. Tubers treated with peppermint oil (PMO) and stored at $10{ }^{\circ} \mathrm{C}$ had shorter sprouts than tubers treated with DMN. 'Kenya Mpya' was more responsive to DMN treatment than 'Shangi' and 'Asante' at the two storage temperatures in the two seasons. In both seasons, the length of sprouts increased the storage time irrespective of the treatments.

\section{Storage temperature, cultivar, and suppressant} effects on sprouts number

Storage temperature effect on sprout number varied significantly among cultivars, treatments, and storage duration (Fig. 2). For 'Shangi', the untreated tubers had the highest number of sprouts at both storage temperatures. At $23{ }^{\circ} \mathrm{C}$, the mean number of sprouts per tuber of 'Shangi' (averaged across weeks) was significantly lower for tubers treated with CIPC, followed by those treated with peppermint oil, DMN and nontreated tubers, respectively. 
Similar trend was observed for this cultivar stored at $10^{\circ} \mathrm{C}$. On the tubers of 'Kenya Mpya', the mean number of sprouts per tuber (averaged across weeks) was significantly lower for those tubers treated with CIPC, followed by DMN, peppermint oil and nontreated tubers. In 'Asante' stored at $23{ }^{\circ} \mathrm{C}, \mathrm{CIPC}$ had the greatest sprout suppressive activity, followed by peppermint oil, DMN and the nontreated tubers. Overall, 'Shangi' had the highest number of sprouts per tuber while the tubers of 'Kenya Mpya' had the lowest mean number at both storage temperatures.
Despite observations of early sprouting on tubers treated with DMN, this treatment mostly suppressed the number of sprouts per tuber compared to the untreated tubers at the completion of the experiment due to drop-off of necrotic sprouts and their eventual removal. Similarly, at $10^{\circ} \mathrm{C}$, the mean number of sprouts per tuber was significantly greater on the untreated tubers than CIPC, DMN and peppermint oil treatments. The sprout numbers per tuber were influenced by storage temperatures and were consistently lower at $10{ }^{\circ} \mathrm{C}$ than at $23^{\circ} \mathrm{C}$, regardless of the cultivars used.

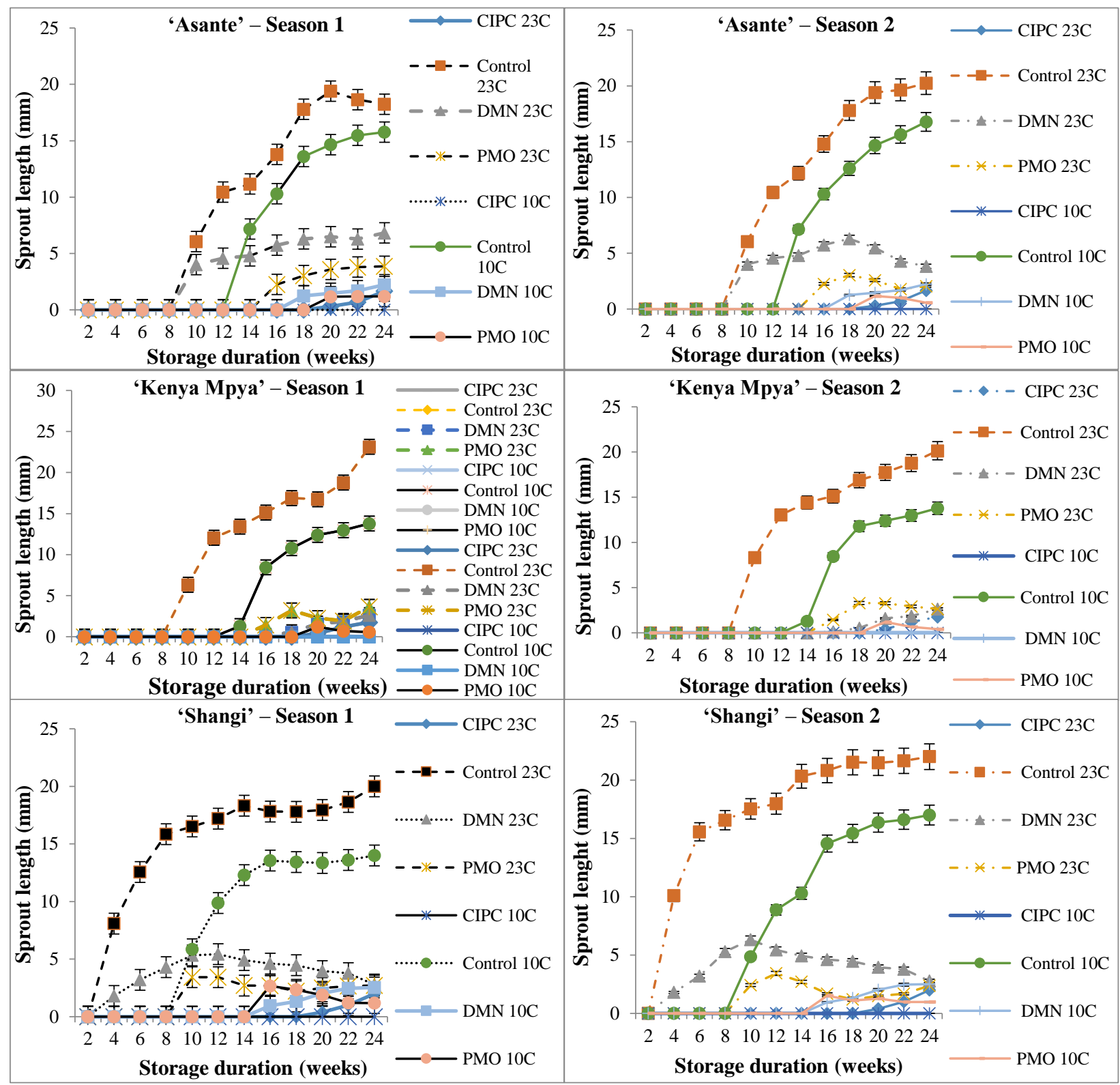

Fig. 1. Effect of storage temperature $\left(23^{\circ} \mathrm{C}\right.$ and $\left.10^{\circ} \mathrm{C}\right)$ on sprout length of three cultivars 'Asante', 'Kenya Mpya', and 'Shangi' following tuber treatment with CIPC, DMN, peppermint oil and untreated stored for 24 weeks 

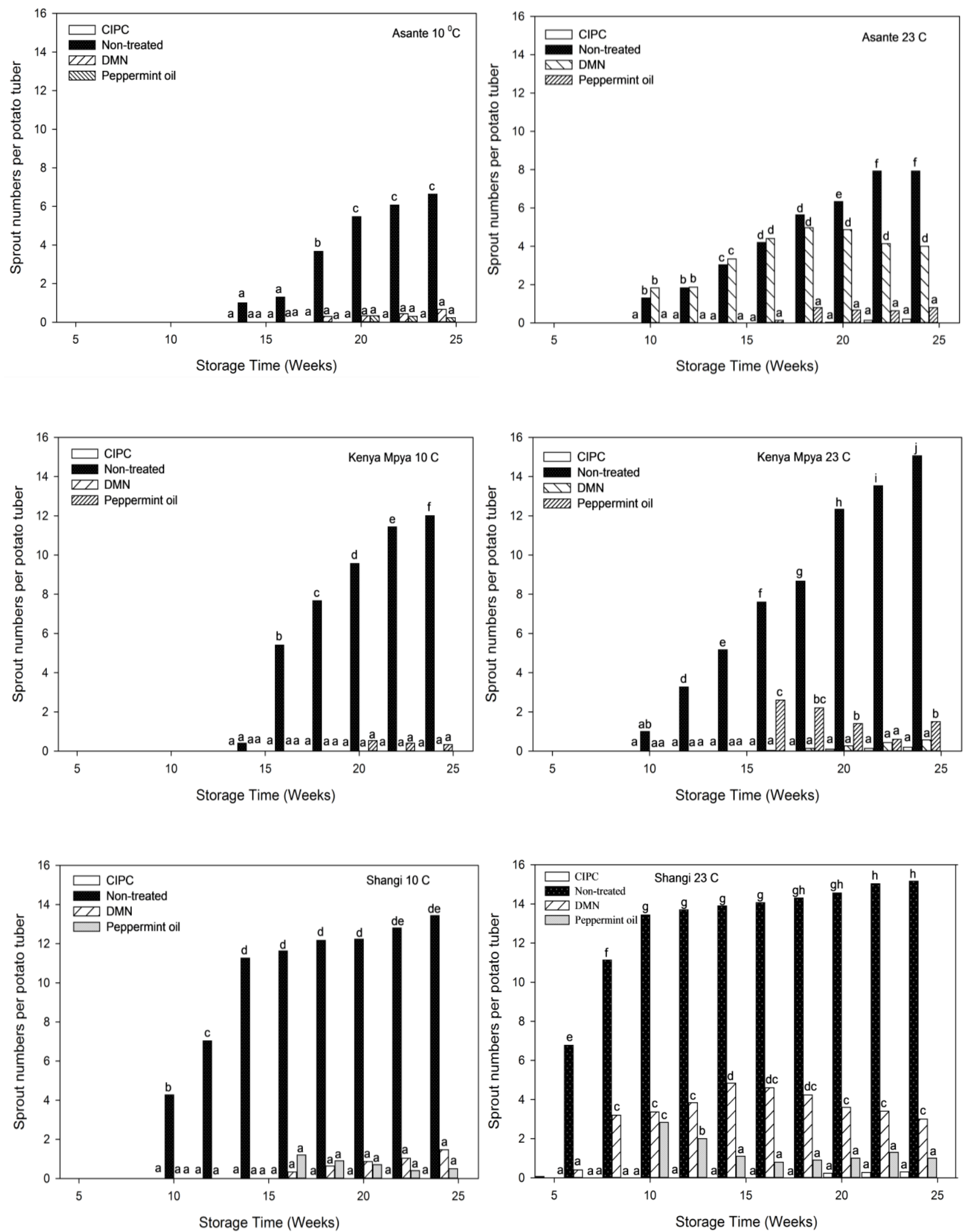

Fig. 2. Effect of storage temperature $\left(10^{\circ} \mathrm{C} ; 23^{\circ} \mathrm{C}\right)$ on sprout number of three cultivars 'Asante', 'Kenya Mpya' and 'Shangi' following tuber treatment with CIPC, DMN, peppermint oil and untreated stored for 24 weeks 


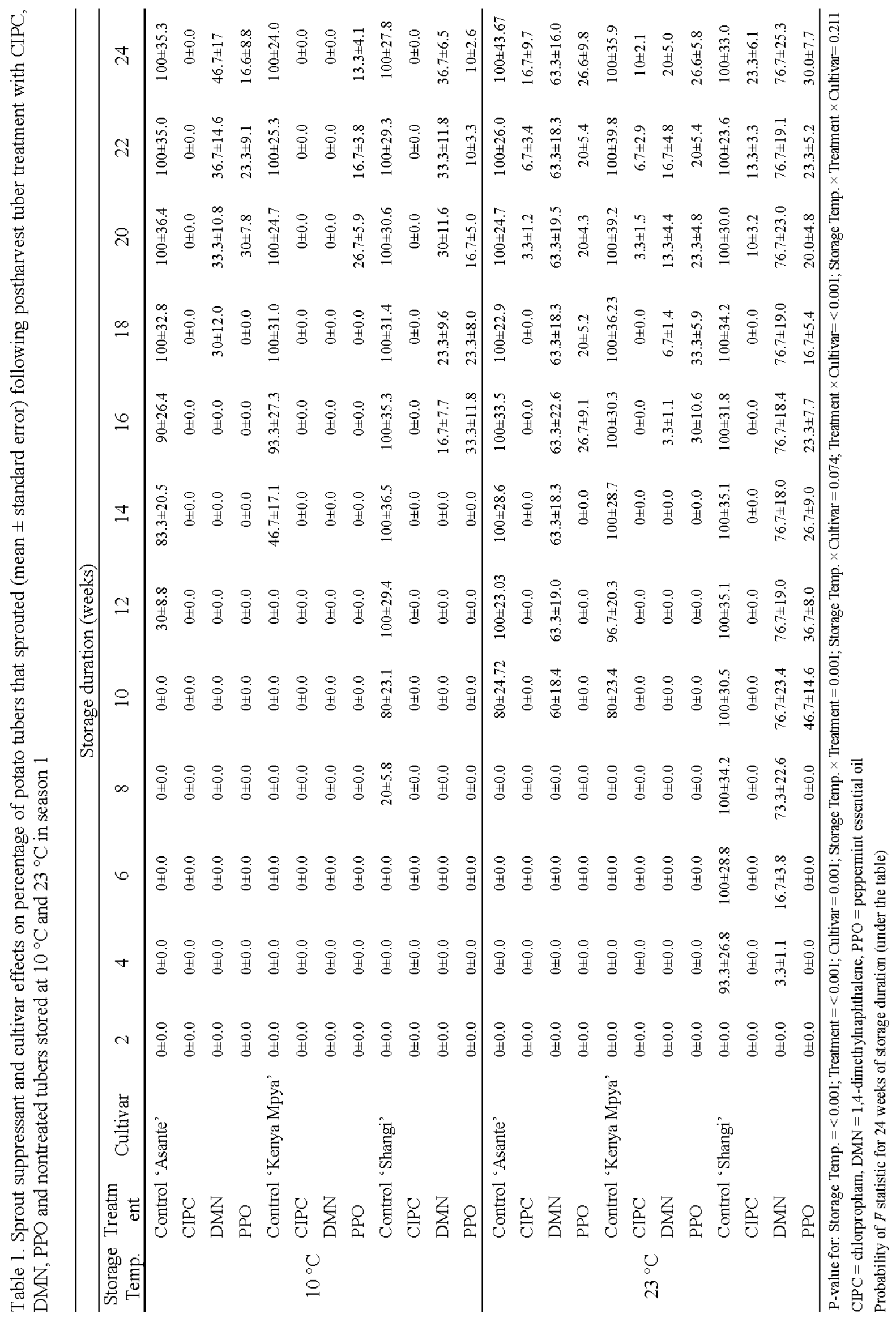




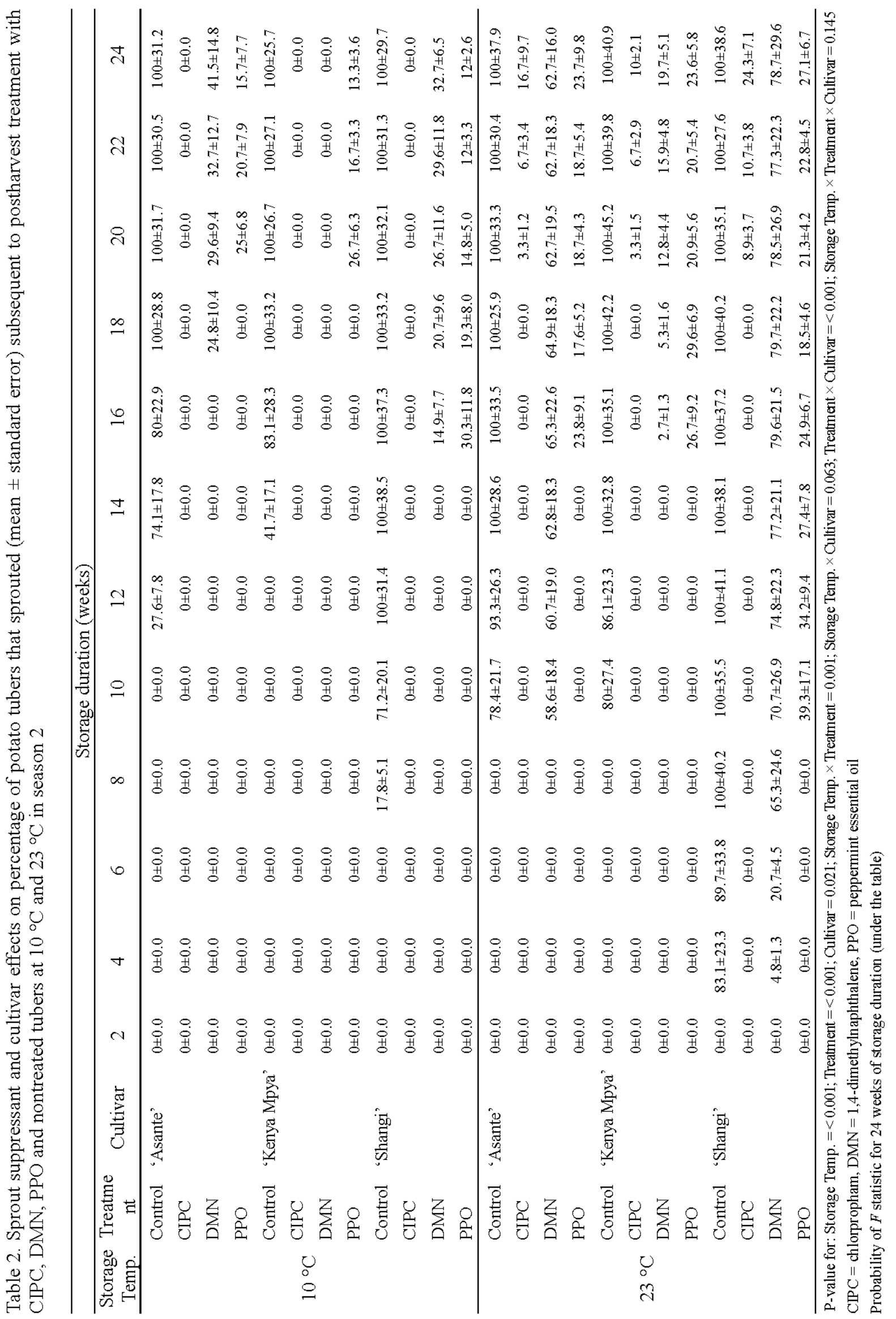




\section{DISCUSSION}

Storage temperatures significantly affected sprout development of potato tubers and lower percentage of tubers with sprouts was recorded at $10{ }^{\circ} \mathrm{C}$ than at $23{ }^{\circ} \mathrm{C}$. Therefore, in the absence of inhibitor applications, tubers from tropical-adapted potato cultivars can be stored at $10{ }^{\circ} \mathrm{C}$ for some duration. Application of synthetic and natural inhibitors delayed and decreased sprouting but both storage temperature and genotype influenced these parameters. In a previous study (Nyankanga et al. 2018), differences in dormancy period of cultivars were recorded and shown to vary with the application of chemical inhibitors under ambient tropical conditions.

The most dramatic effect was achieved with CIPC, which inhibited the germination of all tubers at $10{ }^{\circ} \mathrm{C}$ and up to week 20 at $23{ }^{\circ} \mathrm{C}$, but at this storage temperature, an effect of genotype was observed. Our results are similar to the previous study, which showed the efficacy of CIPC on potato tubers (Mehta \& Kaul 1991; Mehta 2004; Nyankanga et al. 2018; Şanli et al. 2010); however, also some toxicity of CIPC on tubers was observed (Mondy et al. 1992). The same authors reported that tubers treated with CIPC and stored at $5{ }^{\circ} \mathrm{C}$ contained higher residue levels than those stored at $20^{\circ} \mathrm{C}$. The residue levels of CIPC decreased with storage duration (Sakaliene et al. 2008; Singh \& Ezekiel 2010). We hypothesize that the single application of CIPC required for the entire duration of potato storage may be economically feasible for resource-constrained potato farmers in the highland tropics under ambient conditions under which it has been shown to have less residue levels. Therefore, it may be feasible to remove potato tubers treated with CIPC from storage and expose it to elevated temperatures $\left(>25^{\circ} \mathrm{C}\right)$ for several days to minimize residue levels on tubers destined for consumption. In this research, we did not assess the residue levels of CIPC on potato tubers, but hypothesize that due to the longer duration of storage (>20 weeks) under elevated temperatures, residue levels may be quite low (Mehta \& Ezekiel 2003).
Also, DMN and peppermint essential oil were more effective in delaying sprouting at $10{ }^{\circ} \mathrm{C}$ than at $23{ }^{\circ} \mathrm{C}$. On tubers of 'Kenya Mpya' stored at $10{ }^{\circ} \mathrm{C}$, DMN treatment completely inhibited sprout development, suggesting that it could provide complete sprout suppression for tubers of this cultivar but not at $23{ }^{\circ} \mathrm{C}$ as sprout development was recorded. Their inhibiting influence was also dependent on storage temperature and tuber genotype. Inhibition caused by PPO was weaker than DMN at $10{ }^{\circ} \mathrm{C}$ for 'Asante' and 'Kenya Mpya'. At $23^{\circ} \mathrm{C}$, PPO inhibited sprouting weaker than DMN in 'Kenya Mpya' but stronger in 'Asante' and 'Shangi'. The efficacy of essential oil derived from peppermint for sprout inhibition on potato has been previously documented (Song et al. 2008). It has been demonstrated that essential oil (derived from plants), whose composition consisted mainly of monoterpenes and carvone, are effective in reducing sprouting, tuber weight loss and tuber rot over a 225-day storage (Alamar et al. 2017). The sprout inhibition by compounds derived from essential oils of carvone, acts by preventing dormancy break and inhibits sprout growth after dormancy initiation (Oosterhaven et al. 1995). However, because of the volatility of essential oil, it has been suggested that multiple applications of essential oils are needed for inhibition of sprout development on tubers. Additional mode of actions of essential oils were postulated to be associated with disruption of microbial cell membranes. Furthermore, it has been shown that some essential oil contains compounds of the unsaturated ketone group, which inhibits sprout growth (Capelle et al. 1996). Other mechanisms of essential oils have been associated with the degradation of enzymes that are crucial for the biosynthesis of cytokinin, gibberellic acid and abscisic acid, and membrane components of the cell, thereby affecting sprout development.

Sprouts of tubers treated with DMN and stored at $10{ }^{\circ} \mathrm{C}$ had sprout length of $<2.6 \mathrm{~mm}$ throughout the storage duration, while tubers at $23{ }^{\circ} \mathrm{C}$ had greater sprout length ( $\geq 6 \mathrm{~mm}$ ). In this research, we noted that even though tubers of 'Asante' and 'Shangi' treated with DMN sprouted at the same time as untreated tubers following storage at $23{ }^{\circ} \mathrm{C}$, the percentage of sprouting and sprout length were greatly reduced. 
In a similar research, it was reported that two applications of DMN at 200 and $300 \mathrm{mg} \cdot \mathrm{kg}^{-1}$ were equal to CIPC treatment in the dose $22 \mathrm{mg} \cdot \mathrm{kg}^{-1}$ in the suppression of sprout elongation after 295 days in storage at $7{ }^{\circ} \mathrm{C}$ (Lewis et al. 1997).

In this study, it was observed that the number of sprouts at the completion of storage experiment was reduced considerably for 'Shangi' and 'Asante' tubers exposed to DMN treatment. This may have been a consequence of the dry necrotic sprouts dropping from tubers, perhaps due to tuber handling. Therefore, tubers of cultivars that exhibited short dormancy under ambient $\left(23^{\circ} \mathrm{C}\right)$ storage conditions would behave similarly under cold storage $\left(10^{\circ} \mathrm{C}\right)$, when compared to the tubers of cultivars with longer dormancy duration. However, previous researchers noted reduced sprout elongation of tubers subsequent to treatment with DMN and storage at 10 to $17{ }^{\circ} \mathrm{C}$ compared to the untreated tubers (Lewis et al. 1997). Therefore, our research results imply that tuber treatment with DMN suppressed sprout growth and greatly reduced sprout elongation at the two storage temperatures.

\section{CONCLUSIONS}

DMN and peppermint oil, the use of which is not prohibited, also provided comparatively good sprouting inhibition under storage of potato tubers in ambient temperature, indicating that they could be used by resource-constraint potato farmers in tropics as an alternative to CIPC.

\section{REFERENCES}

Alamar M.C., Tosetti R., Landahl S., Bermejo A., Terry L.A. 2017. Assuring potato tuber quality during storage: A future perspective. Frontiers in Plant Science 8; 2034; 6 p. DOI: 10.3389/fpls.2017.02034.

Campbell M.A., Gleichsner A., Alsbury R., Horvath D., Suttle J. 2010. The sprout inhibitors chlorpropham and 1,4-dimethylnaphthalene elicit different transcriptional profiles and do not suppress growth through a prolongation of the dormant state. Plant Molecular Biology 73(1): 181-189. DOI: 10.1007/s11103-010-9607-6.
Campbell M.A., Gleichsner A., Hilldorfer L., Horvath D., Suttle J. 2012. The sprout inhibitor 1,4-dimethylnaphthalene induces the expression of the cell cycle inhibitors KRP1 and KRP2 in potatoes. Functional and Integrative Genomics 12(3): 533-541. DOI 10.1007/s10142-011-0257-9.

Capelle A., Diepenhorst P., Hartmans K.J., Meyer W.J.M. 1996. An anti-sprouting agent for potatoes based on the essential oil of caraway. Proceedings of the IX International Conference on Jojoba and its Uses and of the III International Conference on New Industrial Crops and Products. 25-30 September 1994, Catamarca, Argentina, pp. 466-468.

Chauhan S.S., Prakash O., Padalia R.C., Vivekanand, Pant A.K., Mathela C.S. 2011. Chemical diversity in Mentha spicata: Antioxidant and potato sprout inhibition activity of its essential oils. Natural Product Communications 6(9): 1373-1378. DOI $10.1177 / 1934578 \times 1100600938$

Coleman W.K., Lonergan G., Silk P. 2001. Potato sprout growth suppression by menthone and neomenthol, volatile oil components of Minthostachys, Satureja, Bystropogon, and Mentha species. American Journal of Potato Research 78: 345-354. DOI: 10.1007/bf02884343.

Frazier M.J., Olsen N., Kleinkopf G. 2004. Organic and alternative methods for potato sprout control in storage. University of Idaho Extension, Idaho Agricultural Experiment Station, CIS 1120; $4 \mathrm{p}$. www.info.ag.uidaho.edu/pdf/CIS/CIS1120.pdf

Gustavsson J., Cederberg Ch., Sonesson U., van Otterdijk R., Meybeck A. 2011. Global food losses and food waste. Extent, causes and prevention. Food and Agriculture Organization of the United Nations (FAO), Rome, Italy, 29 p.

Gómez-Castillo D., Cruz E., Iguaz A., Arroqui C., Vírseda P. 2013. Effects of essential oils on sprout suppression and quality of potato cultivars. Postharvest Biology and Technology. 82: 15-21. DOI: 10.1016/j.postharvbio.2013.02.017.

Jaetzold R., Schmidt H., Hornetz B., Shisanya C. 2006. Farm management handbook of Kenya, vol. II. Natural conditions and farm management information of Central Kenya. Ministry of Agriculture, Nairobi, Kenya, 573 p. 
Kleinkopf G.E., Oberg N.A., Olsen N.L. 2003. Sprout inhibition in storage: Current status, new chemistries and natural compounds. American Journal of Potato Research 80(5): 317-327. DOI: $10.1007 / \mathrm{bf02854316.}$

Knowles N.R., Knowles L.O. 2008. Alpha- and betaunsaturated aliphatic aldehydes and ketones constitute a new class of potato sprout inhibitors. Abstracts of Papers Presented at the $91^{\text {st }}$ Annual Meeting of the Potato Association of America, Idaho Falls, Idaho, August 12-16, 2007. American Journal of Potato Research 85: 17. DOI: 10.1007/s12230-008-9000-z.

Lewis M.D., Kleinkopf G.E., Shetty K.K. 1997. Dimethylnaphthalene and diisopropylnaphthalene for potato sprout control in storage: 1. Application methodology and efficacy. American Potato Journal 74(3): 183-197. DOI: 10.1007/bf02851597.

Lung'aho C., Nderitu S.K.N., Kabira J.N., El-Bedewy R., Olanya O.M., Walingo A. 2006. Yield performance and release of four late blight tolerant potato varieties in Kenya. Journal of Agronomy 5: 57-61. DOI: 10.3923/ja.2006.57.61.

Mehta A. 2004. Respiration rate of stored potato tubers: Effect of chemical sprout inhibitors. Indian Journal of Plant Physiology 9(1): 69-74.

Mehta A., Ezekiel F.R. 2003. Evaluation of nonrefrigerated storage methods for short term on-farm storage of potatoes. Journal of the Indian Potato Association 30(3-4): 291-295.

Mehta A., Kaul H.N. 1991. Effect of sprout inhibitors on potato tubers (Solanum tuberosum L.) stored at ambient or reduced temperatures. Potato Research 34(4): 443-450. DOI: 10.1007/bf02360580.

Mehta A., Kaul H.A. 2002. Evaluation of menthol and menthe oil as potato sprout inhibitors. Journal of the Indian Potato Association 29: 107-112.

Mondy N.I., Sharada D., Munshi C.B., Wurm C.M. 1992. Effect of storage time, temperature, and cooking on isopropyl $\mathrm{N}$-(3-chlorophenyl)carbamate levels in potatoes. Journal of Agricultural and Food Chemistry 40(2): 197-199. DOI: 10.1021/jf00014a006.

Nyankanga R.O., Murigi W.W., Shibairo S.I., Olanya O.M., Larkin R.P. 2018. Effects of foliar and tuber sprout suppressants on storage of ware potatoes under tropical conditions. American Journal of Potato Research 95: 539-548. DOI: 1007/s12230-018-9662-0.
Olanya M., Nyankanga R., Ojiambo P., Lemaga B., Kakuhenzire R., Fontem D. 2012. Optimization of late blight and bacterial wilt management in potato production systems in the highland tropics of Africa. In: He Z., Larkin R., Honeycutt W. (Eds.), Sustainable Potato Production: Global Case Studies; pp. 509-531. DOI: 10.1007/978-94-007-4104-1_29.

Oosterhaven K., Poolman B., Smid E.J. 1995. S-carvone as a natural sprout inhibiting, fungistatic and bacteristatic compound. Industrial Crops and Products 4(1): 23-31. DOI: 10.1016/0926-6690(95)00007-y.

Owolabi M.S., Lajide L., Oladimeji M.O, Setzer W.N. 2010. The effect of essential oil formulations for potato sprout suppression. Natural Product Communications $\quad 5(4)$ : 645-648. DOI: 10.1177/1934578x1000500431.

Paul V., Ezekiel R., Pandey R. 2016. Sprout suppression on potato: need to look beyond CIPC for more effective and safer alternatives. Journal of. Food Science and Technology 53(1): 1-18. DOI: 10.1007/s13197-015-1980-3.

Sakaliene O., Koskinen W.C., Blazauskiene G., Petroviene I. 2008. Level and fate of chlorpropham in potatoes during storage and processing. Journal of Environmental Science and Health Part, B 44(1): 1-6. DOI: 10.1080/03601230802519470.

Şanli A., Karadoğan T., Tonguç M., Baydar H. 2010. Effects of caraway (Carum carvi L.) seed on sprouting of potato (Solanum tuberosum L.) tubers under different temperature conditions. Turkish Journal of Field Crops 15(1): 54-58. DOI: 10.17557/tjfc.69413.

Scott G.J., Best R., Rosegrant M., Bokanga M. 2000. Roots and tubers in the global food system. A vision statement to the year 2020. CIP, CIAT, IFPRI, IITA, IPGRI. International Potato Center, Lima, Peru, 112 p.

Singh B., Ezekiel R. 2010. Isopropyl N-(3-chlorophenyl) carbamate (CIPC) residues in potatoes stored in commercial cold stores in India. Potato Research 53(2): 111-120. DOI: 10.1007/s11540-010-9155-0. Smith M.J., Bucher G. 2012. Tools to study the degradation and loss of the N-phenyl carbamate chlorpropham comprehensive review. Environmental International 49: 38-50. DOI: 10.1016/j.envint.2012.08.005. 
Song X., Bandara M., Tanino K.K. 2008. Potato dormancy regulation: Use of essential oils for sprout suppression in potato storage. Fruit, Vegetable and Cereal Science and Biotechnology 2: 110-117.

Sonnewald U. 2001. Control of potato tuber sprouting. Trends in Plant Science 6(8): 333-335. DOI: 10.1016/s1360-1385(01)02020-9.

Teper-Bamnolker P., Dudai N., Fischer R., Belausov E., Zemach H., Shoseyov O., Eshel D. 2010. Mint essential oil can induce or inhibit potato sprouting by differential alteration of apical meristem. Planta 232(1): 179-186. DOI: 10.1007/s00425-010-1154-5. Vaughn S.F., Spencer G.F. 1991. Volatile monoterpenes inhibit potato tuber sprouting. American Potato Journal 68(12): 821-831. DOI: $10.1007 / \mathrm{bf02853856.}$
Vaughn S.F., Spencer G.F. 1993. Naturally-occurring aromatic compounds inhibit potato tuber sprouting. American Potato Journal 70: 527-533. DOI: 10.1007/bf02846753.

de Weerd J.W., Thornton M.K., Shafii B. 2010. Sprout suppressing residue levels of 1,4-dimethylnaphthalene $(1,4 \mathrm{DMN})$ in potato cultivars. American Journal of Potato Research 87: 434-445. DOI: 10.1007/s12230-010-9146-3.

Wiltshire J.J.J., Cobb A.H. 1996. A review of the physiology of potato tuber dormancy. Annals of Applied Biology 129(3): 553-569. DOI: 10.1111/j.17447348.1996.tb05776.x.

Wustman R., Struik P.C. 2007. The canon of potato science: 35. Seed and ware potato storage. Potato Research 50(3): 351-355. DOI: 10.1007/s11540-008-9079-0. 